\author{
Andrzej Lech \\ Uniwersytet Łódzki \\ Interdyscyplinarny Zespół Badania Wsi
}

\title{
Wiktor Mucha - artysta ludowy z Borowia (pow. garwoliński)
}

Wyjątkowy życiorys Wiktora Muchy, Jego dokonania społeczne i artystyczne, stały się przedmiotem zainteresowania etnologów z Uniwersytetu Łódzkiego, prowadzących badania terenowe na terenie ziemi garwolińskiej w latach 1996-2015. Efektem tych działań stało się „odkrycie” naszego bohatera, konkretnie zaś praca magisterska Mariusza Liszewskiego pt. „Wiktor Mucha - autorytet i artysta ludowy z Borowia z Ziemi Garwolińskiej”, Łódź 2006, ss. 132. (promotor: Andrzej Lech).

Najpierw jednak cenne uwagi na temat życia i dorobku Wiktora sformułował Jego brat - franciszkanin o. dr Jan Mucha: „Życie rodziny Aleksandra i Piotra Muchy (We wspomnieniach dzieci)”, Laliny - Łódź - Łagiewniki 2003. W wydawnictwie albumowym, opublikowanym własnym sumptem przez Autora, doceniając walory swego brata, napisał: „Na życie Wiktora duży wpływ miały: dar artystyczno-rzeźbiarski otrzymany od Boga; humor, umiłowanie kobiet i życia towarzyskiego - od Taty; uczuciowość, wrażliwość na potrzeby innych - od Mamy; chętne i częstsze zaglądanie do kieliszka w domu i barze - od diabełka Boruty"

Wyposażeni w tę syntetyczną charakterystykę Wiktora, zajrzyjmy do Jego nietuzinkowego życiorysu, którego zdarzeniami można obdzielić kilku przynajmniej bohaterów minionych i aktualnych czasów, od II wojny światowej, poprzez Polskę Ludową, aż do III Rzeczypospolitej.

Urodził się 10 marca 1937 roku jako pierworodne dziecko Piotra i Aleksandry z domu Sitek. Był „owocem (...) wielkiej i płodnej miłości”2, która w sumie wydała ośmioro dzieci, siedmiu synów i jedną córkę. On, jak zresztą i wszystkie dzieci małżeństwa Muchów, został wychowany pośród wartości chrześcijańskich, uznających autorytet Kościoła katolickiego. Rodzina żyła w pewnym niedostatku materialnym, ale godnie i w wielkiej zacności integrującej rodzeństwo aż po dzień dzisiejszy.

Po Wiktorze przyszedł na świat Edward (27 IX 1939 r.), w kolejności: Klemens (27 VII 1942 r.), Marian (24 III 1946 r.), Jan (19 X 1949 r.), Tadeusz (28 X

\footnotetext{
$1 \quad$ O. dr J. Mucha, Życie rodziny Aleksandry i Piotra Muchy (We wspomnieniach dzieci), Laliny-Łódź-Łagiewniki 2003, s. 104.

2 Ibid., s. 17.
} 
1951 r.), Waldemar (26 XII 1955 r.) i wreszcie wyczekiwana przez matkę Jadwiga (11 IV 1959 r.). Tytułem dygresji dodajmy, że dwóch braci Wiktora wybrało drogi życiowe związane z pełnieniem posłannictwa kapłańskiego religii chrześcijańskiej. Jan, franciszkanin, po obronie doktoratu na Katolickim Uniwersytecie Lubelskim, związał się z łagiewnickim Klasztorem Ojców Franciszkanów św. Jana Chrzciciela w Łodzi, w którym był ekonomem i rektorem w Wyższym Seminarium. Młodszy zaś, Waldemar, n.b. symboliczny chrześniak Bolesława Bieruta (chrzest 22 I 1956 r.) skierowany do pracy misyjnej wśród Polonii amerykańskiej, przyjął święcenia kapłańskie w 1982 roku, podejmując pracę duszpasterską we franciszkańskich ośrodkach Kościoła katolickiego, a później, po konwersji do Kościoła polskokatolickiego, dla Polonii kanadyjskiej.

Wiktor urodził się w domu dziadków ze strony matki, we wsi Laliny (obecnie gmina Borowie). „Wołano na niego Wichcio. Do późnych lat życia używano tego imienia. Wichcio był »maminsynkiem«, karmiony piersią matki ponad rok. Lubił nadal sięgać do »cycka« mamy. Zrobiono mu smoczka z lnianej szmatki, w której był cukier, i gdy zaczął płakać, dawano mu do ssania. Często Wichciem opiekowała się babcia, bo Mama chodziła na zarobek do ludzi na wsi lub dworu”3.

Dzieciństwo spędził w rodzinie, w której rodzice byli miłującymi się i szanowanymi we wsi ludźmi. Bardzo kochali dzieci, choć wymagali, jak to na wsi, już od wczesnych lat zaangażowania w prace w gospodarstwie i opiekę nad kolejnymi, w tej wielodzietnej rodzinie, potomkami.

Byt materialny rodzina Muchów opierała na gospodarstwie rolno-hodowlanym o powierzchni 5 hektarów, w skład którego wchodziła ziemia uprawna i łąki - wszystko w pewnym rozproszeniu, utrudniającym prowadzenie racjonalnej i efektywnej produkcji. Po reformie rolnej z początków Polski Ludowej, w latach 1947-1949, gospodarstwu przybyło jeszcze 1,5 hektara ziemi ornej (tzw. dworskiej), co pozytywnie wpłynęło na plony i pozwoliło „wiązać koniec z końcem”, pomimo przytłaczających tzw. dostaw obowiązkowych. Wprawdzie w poziomie konsumpcji panował w rodzinie ciągły niedostatek, ale liczna gromadka dzieci głodu nie zaznała.

Cała rodzina żyła w niewielkim drewnianym domku konstrukcji zrębowej, postawionym własnymi siłami, prawie wyłącznie przez ojca: „W domu znajdowały się dwa pomieszczenia mieszkalne: pokój i kuchnia, sień i komora, w której przechowywano ziarno i mąkę oraz strych, gdzie przetrzymywano owoce, przetwory i inne rzeczy. W sieni znajdował się przez wiele lat parnik, do parowania ziemniaków dla trzody chlewnej. Była też beczka ogórków kiszonych czy kwaszonej kapusty w okresie zimowym. Sień była też miejscem do prania, najpierw przy pomocy tarki, później przy pomocy pralki »Frania«"4.

Po ukończeniu w rodzinnej wsi szkoły podstawowej Wiktor podjął od jesieni 1952 roku, dalszą naukę w zasadniczej szkole zawodowej w Mińsku Mazowieckim. „Zamieszkał na stancji ok. $1 \mathrm{~km}$ od szkoły. Za pobyt na stancji trzeba było opłacać 30 zł miesięcznie oraz dostarczyć gospodarzowi: kopę kapusty do

\begin{tabular}{ll}
\hline 3 & Ibid., s. 21. \\
4 & Ibid., s. 11.
\end{tabular} 
kiszenia, 30 kg kaszy jęczmiennej, kaszy jaglanej, mąki pszennej ok. 50 kg, drzazgi na rozpałkę i drzewo opałowe, troszkę węgla i kartofli” ${ }^{5}$. Dobrze się uczył i dlatego uzyskał trzykrotnie stypendium w wysokości 175 zł miesięcznie. Wzmocniło to w znacznym stopniu budżet wielodzietnej rodziny.

Po ukończeniu zawodówki rozpoczął burzliwe, ale i bardzo urozmaicone życie pracownicze. Nie został jednak rolnikiem. Już od 1 lipca 1954 roku podjął pracę na oddziale produkcyjnym fabryki ciągników „Ursus” w Warszawie. Wkrótce znudziła Go monotonia tej aktywności i zapragnął zostać zawodowym kierowca. Po zdaniu odpowiednich egzaminów na prawo jazdy, rozpoczął pracę w Zakładach Piekarniczych w Warszawie. Prowadził po mieście ciągnik „Usrus” z dwiema przyczepami.

Również ta praca nie za bardzo zaspokoiła ambicje i ciekawość życia młodego Wiktora. Wraz z kolegami wkrótce rozpoczął pracę w kopalni „Rozbark” w Bytomiu, „,na dole” w systemie trzyzmianowym. Tutaj „czuł ogromne przerażenie (...) gdy w pierwszych dniach jeden z kolegów zginął”.

Po powrocie z kopalni w styczniu 1957 roku wyjechał z domu rodzinnego do pracy w Olsztyńskiem, gdzie zaczął nieźle zarabiać jako traktorzysta likwidujący ugory przed zagospodarowaniem pod produkcję roślinną.

Mimo zapewniającego zadowolenie i stabilność życiową zatrudnienia, musiał w końcu 1957 roku podjąć zasadniczą służbę wojskową jako kierowca samochodu osobowego. Awansował nawet na stanowisko kierowcy szefa sztabu I Korpusu Wojsk Lotniczych w Warszawie. „Cieszył się zaufaniem szefa, ale z dnia na dzień Witek nadużywał tego zaufania. Wiele razy wyruszał samochodem na zabawy z kolegami, czy przyjeżdżał do domu. Jeden taki wyjazd zakończył się rozbiciem samochodu"7. Za ten fantazyjny wyczyn spotkała go niezasłużona i surowa kara w postaci 9-miesięcznego aresztu i więzienia. Karę odbywał w Stargardzie Szczecińskim. W lutym 1959 roku został zwolniony z więzienia i wkrótce także, 20 czerwca 1960 roku, z wojska. Zapewne więc już znacznie spoważniał. W tym miejscu odwołajmy się jednak do pewnej opinii Jego brata, który zaznacza, że „obok samochodów drugą wielką miłością (Wiktora) w latach młodości stały się kobiety”8.

Nim Wiktor ustabilizował swoje życie uczuciowe, przeżył przynajmniej dziesięć mniej lub bardziej efemerycznych związków. Będzie o nich wspominał w kolejnych odsłonach swojego pamiętnika. Ostatecznie, i jak się okazało bardzo szczęśliwie, 27 grudnia 1959 roku ożenił się z Wandą z domu Kępka, rówieśniczką z Borowia, która pracowała w miejscowym ośrodku zdrowia jako asystentka stomatologiczna. Od tego wydarzenia Wiktor „zakotwiczył” w Borowiu (stolica gminy) zamieszkując początkowo u teściów. Po kilku latach oszczędzania wybudował z dużą pomocą brata Tadeusza własny, murowany, piętrowy dom,

\footnotetext{
Ibid., s. 20.

Ibid., s. 25.

Ibid., s. 26.

Ibidem.
} 
w którym z całą rodziną zamieszkał w 1975 roku. Z czasem swoje miejsce znalazły tutaj rodziny córki Urszuli i syna Grzegorza. Dom zaczął tętnić życiem dzieci i wnuków Wiktora.

W harmonijnym związku z Wandą, który przetrwał już 58 lat i został uhonorowany przez Prezydenta RP „Medalem za Długoletnie Pożycie Małżeńskie”, doczekali się Muchowie czworga dzieci: Bogusi (ur. 7 I 1961 r.), Krzysztofa (11 VIII 1962 r.), Urszuli (6 VI 1964 r.) i Grzegorza (29 VIII 1969 r.). Wszystkie one, po zdobyciu pożytecznych społecznie zawodów, pozakładały rodziny i dały Dziadkom spore grono 12 wnucząt. Jedno z nich, Łukasza, ze względu na trudną sytuację rodzinną syna Krzysztofa, przejęli na wychowanie, gdy ten miał zaledwie 6 lat w 1991 roku.

Po powrocie z wojska, jeszcze przed ślubem z Wandą i później, w trakcie dojrzałego życia jako głowa rodziny, Wiktor podejmował szereg wyzwań w pracy zawodowej, w ramach których mógł wykazać się swoją niepospolitą inwencją.

Pracował więc, w niezadługich interwałach czasowych, najpierw w Borowiu w Gminnej Spółdzielni „Samopomoc Chłopska” (GS) przy skupie gęsi, runa leśnego, świń i bydła. Jesienią 1960 roku przez trzy miesiące prowadził skup złomu. Potem zastępował kierownika sklepu spożywczego w niedalekim Gościewiczu, w Borowiu zaś kierował sklepem gospodarstwa domowego, do którego udało się Mu sprowadzić akordeon dla uzdolnionego muzycznie brata Klemensa. Od maja 1962 roku zmienił pracę, zatrudniając się w Wojskowych Zakładach Naprawczych w Celestynowie, jako kierowca samochodu. Po kilku miesiącach, gdy ów zakład rozwiązano, jakiś czas pozostawał bez pracy, ale już od 16 stycznia 1963 roku znów mógł się realizować w swoim ulubionym zawodzie jako kierowca w oddziale garwolińskim Państwowej Komunikacji Samochodowej (PKS).

Zaczął też urozmaicać swoją pracę zawodową jako kierowca prywatnej, nabytej w 1965 roku „Warszawy” M-20: „Ponieważ był to jedyny samochód w Borowiu, zaczął na nim zarabiać, obsługując wesela, chrzciny czy zabawy, czasem »warszawa« służyła jako sanitarka, wożąc chorych do szpitala. Po rozbiciu pierwszej »warszawy« (...) na weselu Mieczysława Chrzyptowicza, kupił drugą (...)”9.

Do końca 1972 roku, po wcześniejszym ukończeniu w Gdańsku kursu na prawo jazdy I kategorii, kierował autobusami kursowymi na terenie powiatu.

Następnie wrócił do pracy w GS w Borowiu, obejmując etat kierowcy - konwojenta. Gdy spółdzielnia ogłosiła upadłość w marcu 1993 roku, po 40. latach pracy zawodowej, skorzystał z możliwości przejścia na wcześniejszą emeryturę. „Wraz z przejściem na emeryturę otrzymał od Zakładu wyprawkę w wysokości 12 milionów starych złotych, za co kupił kosiarkę elektryczną do koszenia trawy, a resztę pieniędzy przeznaczył na wesele syna Grzegorza. Okres emerytury to czas zerwania z nałogiem palenia papierosów. Najbardziej zadowolona była żona Wandzia, która mogła wreszcie pocałować w usta męża, a nie w »popielniczkę«"10.

\begin{tabular}{ll}
\hline 9 & Ibid., s. 90. \\
10 & Ibid., s. 91.
\end{tabular} 
Wcześniejsza emerytura nie oznaczała dla Wiktora zahamowania aktywności społecznej. Ponieważ Polska jest dla niego, niezależnie od zmian ustrojowych, ojczyzną wymagającą zaangażowania i prac na rzecz otaczającego Go środowiska społecznego, to już w latach nauki szkolnej, zaczął dawać temu oryginalny, choć może nie zawsze spontaniczny, wyraz.

Podczas nauki w szkole zawodowej został „przymusowo” członkiem Związku Młodzieży Polskiej ${ }^{11}$, a że było to w czasach stalinowskiej kolektywizacji wsi, to „jako agitator w soboty wyjeżdżał z kolegami do wioski, by zakładać organizacje młodzieżowe” ${ }^{12}$. Natomiast samodzielną aktywnością wykazał się jako założyciel szkolnego koła Ligi Obrony Kraju ${ }^{13}$ i pierwszy przewodniczący tej organizacji w ramach której założył „koło modelarskie samolotów i szybowców”14.

Podejmując pracę w GS wstąpił do Polskiej Zjednoczonej Partii Robotniczej (PZPR) i jednocześnie zaczął aktywizować się w Ochotniczej Rezerwie Milicji Obywatelskiej (ORMO) ${ }^{15}$. W ramach tej organizacji brał udział w utrzymaniu porządku i bezpieczeństwa wewnętrznego na terenie gminy: „Nocami jeździł z milicją po wioskach na kontrole sklepów, obiektów gminnych czy obsługi zabaw $(\ldots) "$.16 .

W latach 70. XX wieku, jako kierowca autobusu w PKS zaangażował się również w działalność samorządu zawodowego. Został wybrany do Rady Robotniczej tej instytucji w Garwolinie.

Jego autorytet został też wykorzystany w funkcjonowaniu PZPR, jako sekretarza Podstawowej Organizacji Partyjnej w zakładzie pracy, a nawet jako członka Komitetu Powiatowego PZPR przed reformą administracyjną z 1975 roku. Wiktorowi nie przeszkadzało to w realizowaniu swojej niekoniunkturalnej wrażliwości społecznej, gdy „,...) powstał w Borowiu Związek Solidarności (...) został przewodniczącym tego związku (...). W czasie stanu wojennego (...) znalazł się w trudnej sytuacji z powodu udziału w solidarności, to groziło aresztem,

$\overline{11}$ Związek Młodzieży Polskiej - masowa organizacja młodzieżowa, powstała w 1948 r. z połączenia Związku Walki Młodych, Organizacji Młodzieży Towarzystwa Uniwersytetu Robotniczego, Związku Młodzieży Wiejskiej RP „Wici” i Związku Młodzieży Demokratycznej. Realizowała podstawowe założenia ideowo-polityczne Polskiej Zjednoczonej Partii Robotniczej pod której kierownictwem miała za zadanie „budowanie podstaw socjalizmu w PRL”. Rozwiązana w 1956 roku. Por. Encyklopedia Popularna PWN, Warszawa 1962, s. 899.

12 O. dr J. Mucha, op. cit., s. 23.

13 Liga Obrony Kraju - masowe stowarzyszenie społeczne wyższej użyteczności w PRL z głównym celem umacniania obronności kraju poprzez rozwijanie działalności szkoleniowej, społecznie użytecznej i wychowawczej. W latach 1945-1950 jako Towarzystwo Przyjaciół Żołnierza, a w latach 1950-1962 Liga Przyjaciół Żołnierza. Por. Encyklopedia..., s. 410.

14 O. dr J. Mucha, op. cit., s. 23.

15 Ochotnicza Rezerwa Milicji Obywatelskiej - organizacja społeczna użyteczności w PRL, powstała w 1946 r., współdziałająca z Milicją Obywatelską w utrzymaniu porządku i spokoju publicznego. Por. Encyklopedia..., s. 532.

16 O. dr J. Mucha, op. cit., s. 91. 
ale ponieważ był równocześnie członkiem straży, PZPR i ORMO, nie doszło do aresztowania, lecz pozostawiono go pod ścisłą kontrolą władz"17.

Swoją aktywność społeczną wykorzystał jednak najbardziej jako działacz ochotniczych straży pożarnych (OSP) na terenie swojej gminy ${ }^{18}$. Tuż po ukończeniu zasadniczej służby wojskowej został przyjęty do tej samopomocowej organizacji społecznej. Odtąd zaczął nadawać ton działalności operacyjnej, prewencyjnej i społeczno-kulturalnej miejscowej straży. Nim, po przejściu na emeryturę, został honorowym członkiem OSP, pełnił w niej funkcje bardzo prestiżowe i jednocześnie wymagające pracowitości i dużej pomysłowości. Był między innymi, w latach 1973/1974, naczelnikiem jednostki, a od 1974 do 2000 roku komendantem dla wszystkich straży ochotniczych na terenie gminy. „Witek jako prezes zobowiązany był do wyjazdów do pożarów oraz organizowania zabaw, loterii fantowych, bali sylwestrowych, a także do organizowania wycieczek. Do jego obowiązków należało czuwanie nad zarybianiem stawu" ${ }^{\text {"19 }}$. Prowadził więc również działalność gospodarczą, której zresztą efekty przyczyniły się do zakupu sprzętu wzbogacającego wyposażenie miejscowych strażaków, m.in. nowoczesnej motopompy.

Jako artysta ludowy, nieprofesjonalny, swoją urozmaiconą w typie i formie twórczość mógł rozwinąć dopiero po przejściu na emeryturę. Jednak już wcześniej dał się poznać jako posiadacz nieprzeciętnego i samorodnego talentu. Spełnia, choć właściwie w zasadzie, kryteria, które pozwalają nazwać Go „artystą ludowym”. Zajmuje się bowiem sztuką nawiązującą w swej treści do elementów kultury tak materialnej, jak i duchowej, które odnajduje w najbliższym regionie, na wsi, ojczyźnie małej i osobistej. Przy tym mieszka na wsi, choć trudno jednoznacznie zaliczyć Go do warstwy chłopskiej. W Jego przypadku pochodzenie i specjalnie okazywany szacunek dla zwyczajów i obyczajów tradycyjnej kultury, kryteria te wypełniają.

Już w szkole podstawowej, bodaj w 7 klasie, wykazał się oryginalnym talentem artystycznym. Narysował kredą na tablicy „,wodzów rewolucji proletariackiej Marksa, Engelsa, Lenina i Stalina”20. Dzieło to okazało się satyryczne w swojej wymowie, ale nie przysporzyło, dobrze zapowiadającemu się artyście, kłopotów (działo się to przecież w 1952 roku), gdyż wzbudziło uznanie u nastawionego antystalinowsko kierownika szkoły.

Kolejny epizod dotyczący twórczości Wiktora, choć na razie działań z pogranicza rzemiosła, czy sztuki użytkowej, miał miejsce podczas Jego pobytu w więzieniu w Stargardzie Szczecińskim: „,...) tam na izbie chorych był taki lekarz wojskowy (...) i tam jeden z (...) więźniów wiersze układał, i ja się zgłosiłem, że do tych wierszy będę rysunki robił. No i bardzo chętnie się zgodził. Dał mi

17 Ibid., s. 95.

Por. Ł. Ufel, Borowie w Ziemi Garwolińskiej. Studium historyczno-etnologiczne osady wiejskiej, Łódź 2006, ss. 129 (praca magisterska napisana w Instytucie Etnologii i Antropologii Kulturowej pod kierunkiem prof. Andrzeja Lecha). O. dr J. Mucha, op. cit., s. 93.

20 M. Liszewski, Wywiad z Wiktorem Muchą, nr 1, lipiec-sierpień 2005 r. (archiwum prywatne M. Liszewskiego). 
kredki (...) no i narysowałem mu (...) To bardzo się podobało. W związku z tym dostałem się na celę plastyczną. Dla artystów. Tam była jakaś cela specjalna, w której artyści siedzieli. Podpadli i tam siedzieli (...) Więc właśnie się dostałem do tych artystów. Tam (...) jeden taki więzień, starszy pan nauczył mnie jak robić portrety ze zdjęć (...) Myśmy robili tam (ze słomy) papierośnice, puderniczki dla kobiet, to znów jakieś inne pudełka, obrazy żeśmy robili (...) I każdy jakieś części tam robił. Tam liście miałem robić to robiłem tylko liście. Każdy miał swoje. I potem ten główny składał to. Grafika była. Sprzedawali to i ze sprzedaży 25\% żeśmy dostawali”21.

Nie ulega wątpliwości, że talent artystyczny naszego bohatera rozwinął się w pełni dopiero wówczas, gdy przeszedł On na emeryturę i zaczął dysponować większym czasem wolnym. Wówczas podjął i odpowiednio wycyzelował zasadniczy typ swojej twórczości, czyli rzeźbiarstwo. Samodzielnie dochodził, poprzez wieloletnie doświadczenie i wykorzystanie oryginalnych pomysłów, do podziwianych, nie tylko we własnym środowisku społecznym, efektów twórczości.

Ulubionym rodzajem tworzywa przy rzeźbieniu, ale także wypalaniu i malowaniu obrazów, jest dla Wiktora drewno. Traktuje je w sposób wyjątkowy, personifikując jak bliską sobie istotę. Stwierdza: „Ja najczęściej robię z drewna. W drewno to się wkłada duszę. Czuję, że to drzewo żyje ze mną"22. Rzeźby wykonuje z jednego kolca, najczęściej lipowego, co jest umiejętnością niełatwą, ale wzbudzającą podziw m.in. zawodowych rzeźbiarzy.

Spośród Jego wielu dzieł, zdobiących remizy straży pożarnych, domów kultury, kościoła i prywatnych kolekcji, na szczególną uwagę zasługuje monument w wysokości 2,5 m, przedstawiający św. Floriana, patrona strażaków. Jest to dar dla wieloletniego przyjaciela Artysty, starszego brygadiera, komendanta powiatowego Państwowej Straży Pożarnej w Garwolinie, Wiesława Wieriaszki. Obiekt ten „wprowadza” do siedziby straży i symbolicznie zapewnia powodzenie wszelkim akcjom ratowniczym na tym terenie.

Inne dzieła Wiktora, utrzymane w duchu realistycznym i prostym, chociaż pomalowane to m.in.: Jezus Frasobliwy oraz naturalnej wielkości rzeźby stojące przed Jego domem, przedstawiające wiejskie postacie w strojach ludowych: dziewczynę, kobietę i tzw. dziadka. Jest wśród nich herb Borowia, szopka bożonarodzeniowa, samolot w okresu II Rzeczypospolitej.

Specjalizuje się również w tworzeniu płaskorzeźb. Wśród nich na wyróżnienie zasługuje „Jezus w Grójcu”, dedykowany bratu o. dr. Janowi na jubileusz kapłaństwa.

Traktując swą twórczość jako użyteczną i realizując własne upodobania estetyczne, zaczął z czasem tworzyć w zupełnie dla siebie nowej i nietradycyjnej technice, mianowicie na bazie wykorzystania betonu jako tworzywa. Najpierw stworzył wędkarza: „Jak oczko u siebie zrobiłem wodne (...) to zrobiłem rybaka takiego i to do dziś dnia tu jest”23.

$\begin{array}{ll} & \\ 21 & \text { Ibidem. } \\ 22 & \text { Ibidem. } \\ 23 & \text { Ibidem. }\end{array}$ 
Rzeźbiąc, pracuje przy pomocy prostych narzędzi, przed wszystkim dłutek, które sam zrobił z wąskich zezłomowanych resorów samochodowych i „takiego młoteczka drewnianego (który) zrobiłem, i se stukam”24. Wykorzystuje również nowoczesne narzędzia, takie jak elektryczne szlifierki i wiertarki. Między innymi, w ten sposób stworzył wiele „grzybków” sporych rozmiarów, sięgających $1 \mathrm{~m}$.

W swojej pracy stosuje także techniki malarskie. Tworzy na sklejce, przy pomocy farb akwarelowych, pokrywanych bezbarwnym lakierem. W tej formie przedstawia portrety świętych, czy sceny z minionego życia codziennego na wsi. Podobnie, rysując obrazki wypalane na brzozowym drewnie, przedstawia motywy sakralne, polowania, kuligi, wiatraki...

Bogate uzdolnienia artystyczne wykorzystuje także przy wykonywaniu licznych napisów i epitafiów na grobach, różnorakich szyldów oraz tablic informacyjnych. Opracowuje wizualnie obchodzone w Borowiu święta kościelne, szczególnie procesje z okazji Bożego Ciała.

W oryginalnym dorobku artystycznym Wiktora odnajdziemy także artefakty z dziedziny tzw. małej architektury. Stworzył bowiem, według całkowicie własnego pomysłu, na terenie swojej posesji, altankę ogrodową, wyposażając ją w rzeźby i obrazy, z grillem i głową błazna Stańczyka, która w pierwszej wersji należała do diabła Boruty.

Osobnym działem twórczości Wiktora jest literatura. Jego aktywność pisarska rozwinęła się w pełni w zasadzie po przejściu na emeryturę, choć już wcześniej, od lat młodości, wykazywał się znacznymi osiągnięciami w zakresie epistolografii. Pisywał ładnie, a nawet wzruszająco do rodziców, rodzeństwa, bądź licznych koleżanek.

Najpełniej talent literacki Wiktora rozbłysnął jednak konkretnie od marca 1993 r., czyli od rozpoczęcia zapisywania pamiętnika, a z czasem dziennika, którego pierwszy fragment publikujemy obok. Głównym motywem napisania tego refleksyjnego dzieła była chęć, jak sam oznajmia, pozostawienia czegoś po sobie, czegoś trwalszego, swoistej pamiątki dla dzieci, wnuków i w ogóle potomnych.

Powstała obszerna praca, licząca już ponad 2 tys. stron, zapisanych w albumowym poszycie, formatu A4, dwustronnie przy pomocy długopisu i ołówków. Jest bogato zaopatrzona w rysunki autorskie i fotografie. Przedstawia losy rodziców Wiktora i w ogóle antenatów. Opisuje dzieciństwo naszego bohatera przypadające na czas okupacji niemieckiej, a także przedstawia późniejsze wydarzenia z Jego bogatego życiorysu. Wszystko to zapisuje na tle wydarzeń otaczającej rzeczywistości, zawierające refleksje dotyczące życia codziennego, spraw społecznych, gospodarczych i politycznych, z bardzo osobistym komentarzem. Dzięki temu „Moje życie” Wiktora posiada kapitalne znaczenie dla badaczy, szczególnie dla etnologów, jako źródło wzbogacające niezbędnie ich warsztat naukowy.

24 Ibidem. 
Akcja spisywana mozolnie, już 25 lat, pamiętnika-dziennika toczy się przeważnie na obszarze, który umownie określamy jako ziemia garwolińska. Aktualnie jest to północno-wschodni obszar powiatu garwolińskiego (gmina Borowie: Laliny - miejsce urodzenia, dzieciństwa i młodości Wiktora, Iwowe, Chromin, Borowie - miejsce dojrzałego życia rodzinnego, artystycznego i społecznego, oraz wsie okoliczne) i południowy skraj powiatu mińskiego (Redzyńskie).

Dodajmy jeszcze, że prowadzenie pamiętnika-dziennika dało Wiktorowi asumpt do znacznego urozmaicenia własnej twórczości literackiej. Ubogacił bowiem całość zawartej tutaj narracji licznymi wierszami, bajkami i legendami we własnej interpretacji, anegdotami i dowcipami, generalnie o zabarwieniu satyrycznym.

Są pewne wartości integrujące naszego bohatera z innymi twórcami. Do nich należy natchnienie. Sam artysta ów stan psychoemocjonalny określa następująco: „(...) mam natchnienie i widzę, że coś jest to wstaję nieraz o 4 rano i stukam (...) bo mi to ułatwia, a nieraz to przyjdzie czas, że (jest) niechęć, nic nie robię, bo nie mam po prostu natchnienia”25.

Poza tym, łatwo zauważyć, że dorobek artystyczny Wiktora nie byłby tak bogaty, oryginalny i wielostronny, gdyby nie Jego talent. Jako osoba głęboko wierząca, dostrzega rolę Stwórcy w ukształtowaniu tej cechy własnego zmysłu twórczego. Wspomina: , Tak się kiedyś bałem pierwszego Floriana zrobić. Kloc metr średnicy, 3 m długości, i co z tego zrobić? Jednak się zrobiło przy pomocy boskiej. Tutaj też nie jestem bohaterem, tylko zależy jak Pan Bóg pomaga. Dał talent, ale samemu nie można nic zrobić”26.

Cechą Mistrza jest też skromność. Wprawdzie cieszy się On uznaniem środowiska, w którym żyje, animatorów kultury i działaczy samorządowych; wprawdzie swoimi pracami wzbogaca wystawy (m.in. w: Garwolinie, Bielawie i Borowiu) i prywatne kolekcje, ale pyta samego siebie: „A czy ja jestem artystą? Bo ja wiem? Może i jestem. Ludzie nazywają mnie artystą ludowym (...) Ja to za słaby jestem, a przecież jak ja widzę $\mathrm{w}$ telewizji, tam jakie rzeźby robią. To naprawdę rzeźbią"27.

Stworzone przez siebie dzieła zachowuje we własnym obejściu lub czyni z nich cenione prezenty rodzinie, instytucjom samorządowym, znajomym i osobom, które nadzwyczaj ceni, aby w ten sposób symbolicznie zaliczyć je do grona najbliższych przyjaciół.

Należy podkreślić, iż olbrzymią rolę w stworzeniu Wiktorowi odpowiedniego klimatu twórczego, odgrywa Jego najbliższe otoczenie społeczne - gromada wiejska. Mieszkańcom Borowia podoba się twórczość bliskiego sąsiada; może także dlatego, że jest czytelna, zrozumiała i wypełniająca lokalne poczucie

\footnotetext{
25 Ibidem.

26 Ibidem.

27 Ibidem.
} 
estetyzmu. Przy tym dodaje swoistego kolorytu całej wsi i dlatego borowianie są dumni z tego, że pośród nich żyje ktoś taki jak Wiktor Mucha.

Ponieważ Wiktor nie traktuje swojej aktywności twórczej w sposób komercyjny, jak już zaznaczyliśmy często darowuje efekty owej pracy osobom prywatnym i różnym instytucjom społeczno-kulturalnym, to jedyną dla niego formą wynagrodzenia jest uznanie i szacunek jakim cieszy się wśród mieszkańców Borowia i całej ziemi garwolińskiej. I to właśnie buduje zasłużony autorytet w tej Jego małej ojczyźnie. Gdyby w literaturze pięknej poszukać postaci, której cechy psychospołeczne możnaby skojarzyć z Wiktorem, to z pewnością mógłby to być Colas Breugnon, tytułowy bohater powieści francuskiego pisarza Romaina Rollanda (1866-1944), wydanej po raz pierwszy w Polsce w 1921 roku. Podobnie jak on promieniuje pokojowym nastawieniem do otaczającej rzeczywistości; upowszechnia idee piękna, wprawdzie nie zawsze wysublimowanego, nieco naturalistycznego, ale niosącego z sobą osobisty powiew swobody, wolności. Również jak Breugnon jest uosobieniem ludowego optymizmu, który u Niego może przybierać postać rubaszności, uwidacznianej nie tyle w ciepłych i radosnych kontaktach towarzyskich, co w twórczości poetyckiej. Okazuje się, że trwanie w środowisku lokalnym może też wykreować postać o cechach iście renesansowych, zaznaczających swoją twórczą obecność oryginalnym dorobkiem artystycznym i spolegliwą działalnością społeczną. Dlatego można stwierdzić, bez przesady, iż Wiktor Mucha jest człowiekiem zwyczajnym, ale jednocześnie niezwykłym w swoim życiu i dokonaniach.

Ad multos annos, Drogi Wiktorze!

Andrzej Lech

Współpraca: Mariusz Liszewski 


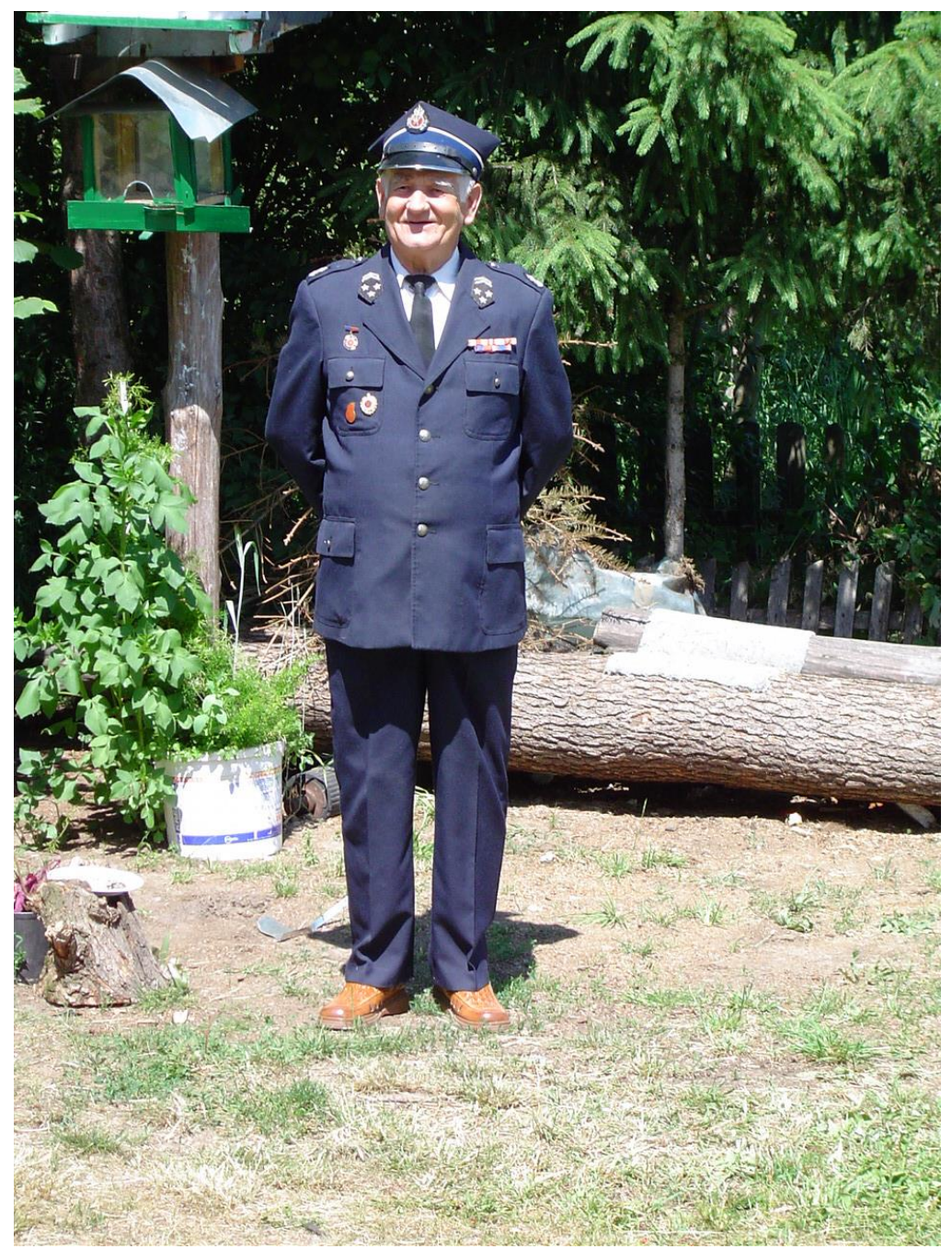

Ryc. 1. Wiktor Mucha (fot. M. Liszewski) 


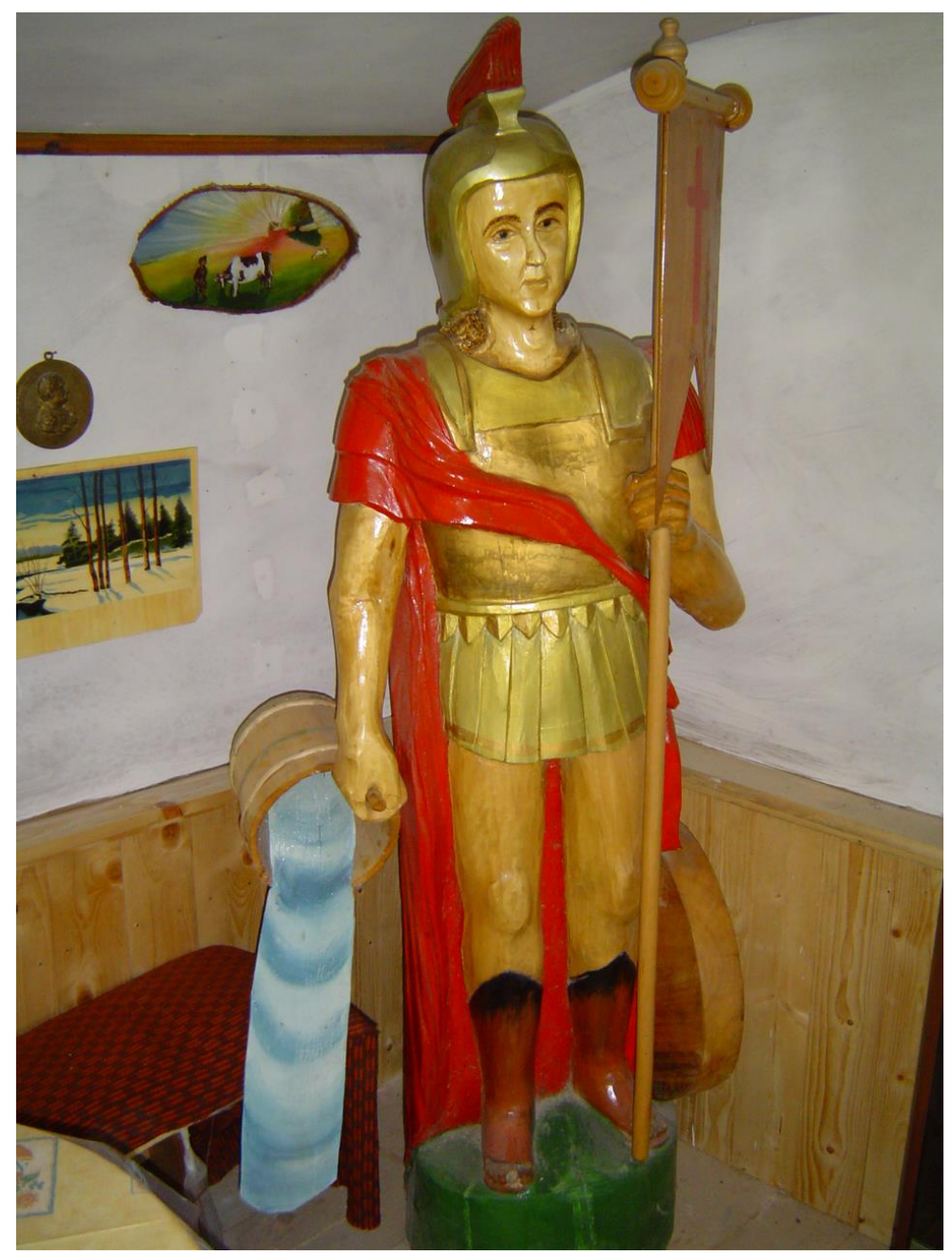

Ryc. 2. Św. Florian (fot. M. Liszewski) 


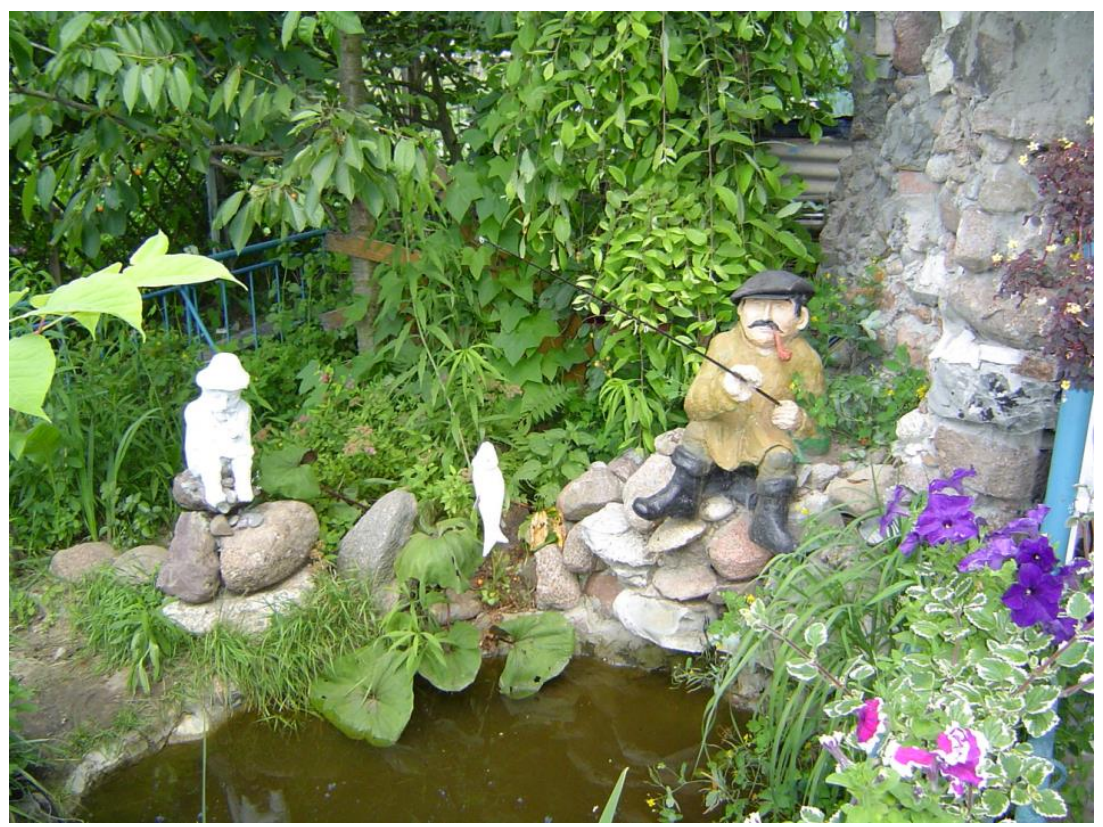

Ryc. 3. Rybak - pierwsza betonowa rzeźba Wiktora Muchy (fot. M. Liszewski) 


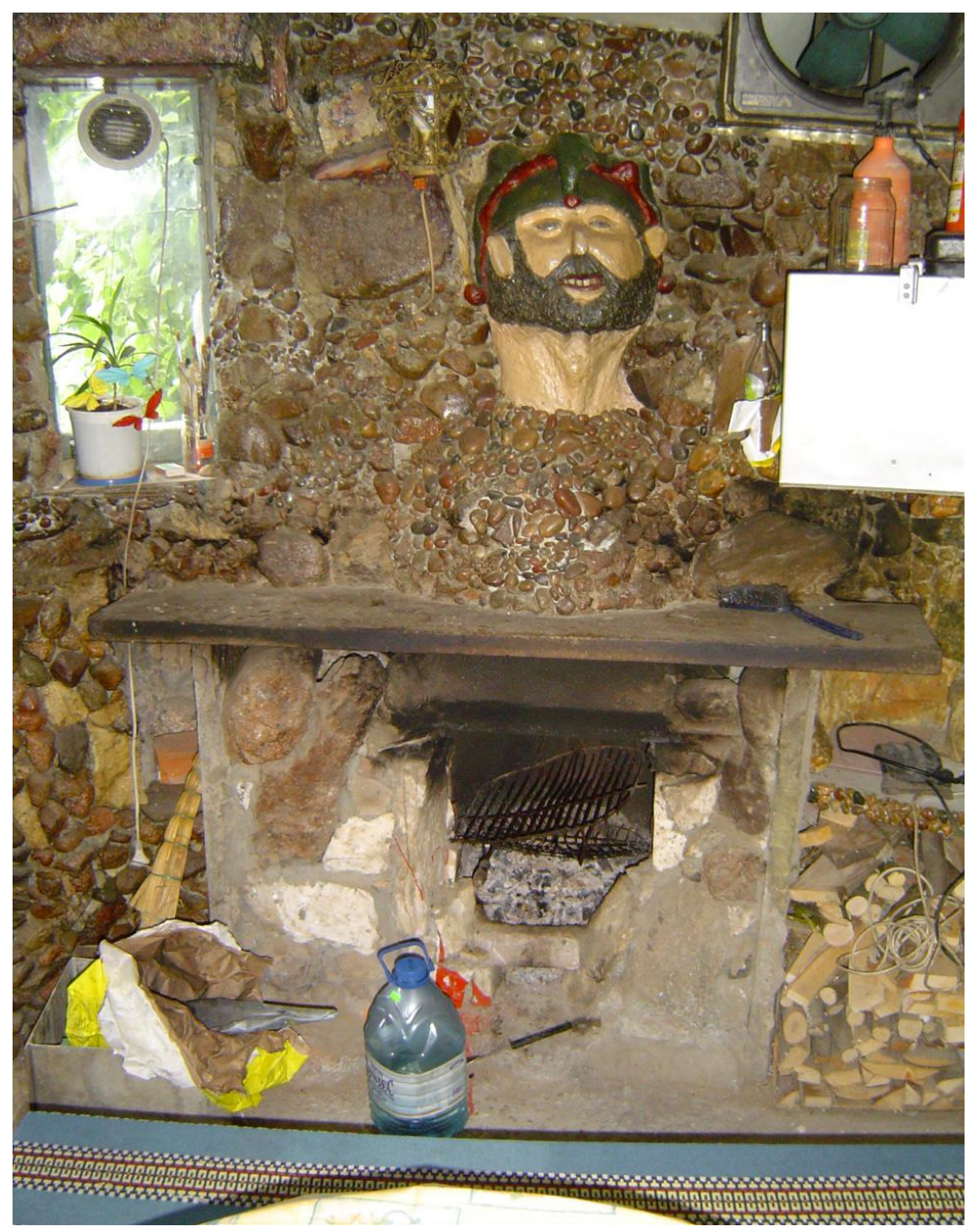

Ryc. 4. Grill ogrodowy (fot. M. Liszewski) 


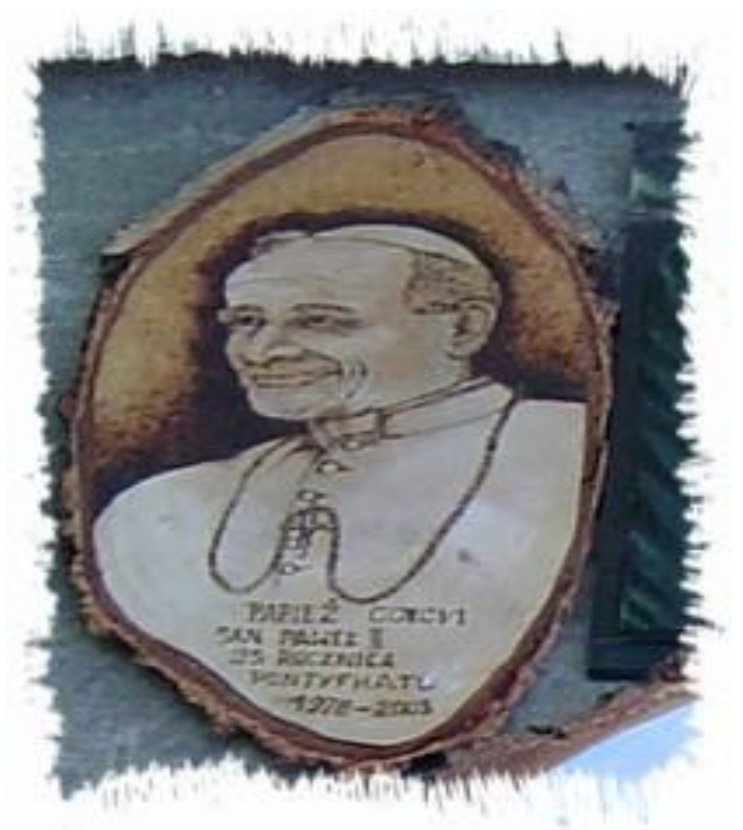

Ryc. 5. Papież - obraz wypalany na brzozie (fot. M. Liszewski)

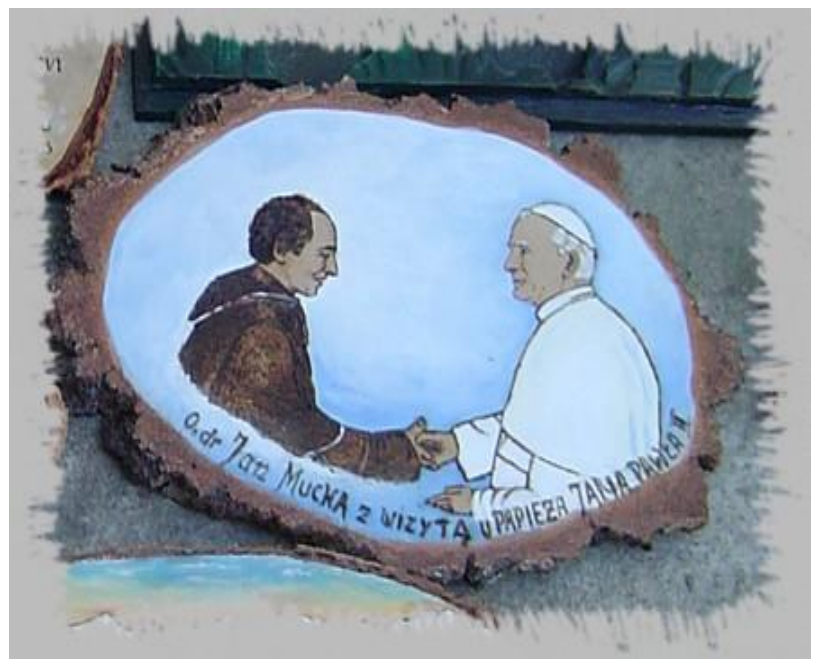

Ryc. 6. O. dr Jan Mucha z wizytą u Papieża Jana Pawła II (fot. M. Liszewski) 


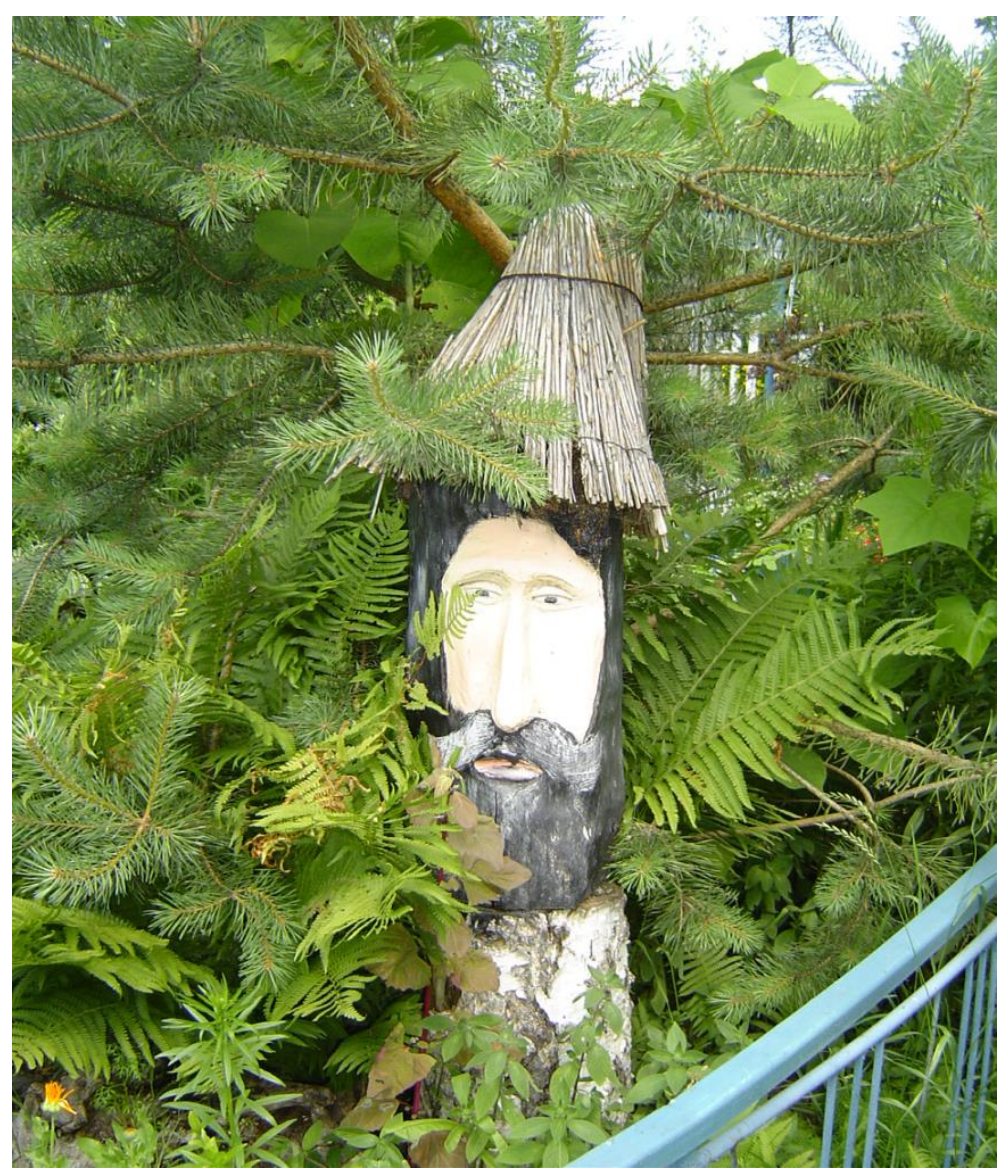

Ryc. 7. Ul wyrzeźbiony w kształcie ludzkiej głowy (fot. M. Liszewski) 